\title{
Comparative study of isotopic trends in two coastal ecosystems of North Biscay: A multitrophic spatial gradient approach
}

\author{
J.M. Mortillaro ${ }^{b, d, *}$, G. Schaal ${ }^{a, b}$, J. Grall ${ }^{b}$, C. Nerot ${ }^{a, d}$, A. Brind'Amour ${ }^{c}$, V. Marchais ${ }^{a}$, M. Perdriau ${ }^{d}$, \\ H. Le Bris ${ }^{d}$
}

\begin{abstract}
a UMR-CNRS-IRD 6539, LEMAR, IUEM, Université de Bretagne Occidentale, Place Nicolas Copernic, 29280 Plouzané, France

${ }^{b}$ UMS 3113, Observatoire des Sciences de I'Univers, IUEM, Place Nicolas Copernic, 29280 Plouzané, France

c Unité EMH, Ifremer Nantes, Rue de l'île d'Yeu, BP 21105, 44311 Nantes Cedex 03, France

d Agrocampus-Ouest, UMR 985, Ecologie et Santé des Ecosystèmes, 65 rue de St. Brieuc, 35042 Rennes,
\end{abstract} France

*: Corresponding author : J. M. Mortillaro, email address : mortillaro@mnhn.fr

\begin{abstract}
:
In coastal estuarine embayments, retention of water masses due to coastal topography may result in an increased contribution of continental organic matter in food webs. However, in megatidal embayments, the effect of topography can be counterbalanced by the process of tidal mixing. Large amounts of continental organic matter are exported each year by rivers to the oceans. The fate of terrestrial organic matter in food webs of coastal areas and on neighboring coastal benthic communities was therefore evaluated, at multi-trophic levels, from primary producers to primary consumers and predators. Two coastal areas of the French Atlantic coast, differing in the contributions from their watershed, tidal range and aperture degree, were compared using carbon and nitrogen stable isotopes $\left(\delta^{13} \mathrm{C}\right.$ and $\left.\delta^{15} \mathrm{~N}\right)$ during two contrasted periods. The Bay of Vilaine receives large inputs of freshwater from the Vilaine River, displaying ${ }^{15} \mathrm{~N}$ enriched and ${ }^{13} \mathrm{C}$ depleted benthic communities, emphasizing the important role played by allochtonous inputs and anthropogenic impact on terrestrial organic matter in the food web. In contrast, the Bay of Brest which is largely affected by tidal mixing, showed a lack of agreement between isotopic gradients displayed by suspended particulate organic matter (SPOM) and suspension-feeders. Discrepancy between SPOM and suspension-feeders is not surprising due to differences in isotopes integration times. We suggest further that such a discrepancy may result from water replenishment due to coastal inputs, nutrient depletion by phytoplankton production, as well as efficient selection of highly nutritive phytoplanktonic particles by primary consumers.
\end{abstract}

\section{Highlights}

- We investigated the impact of terrestrial material on adjacent coastal communities. Seasonal changes in stable isotopes signatures of two estuarine bays were monitored. Consumers trophic ecology was driven by freshwater inputs in the Bay of Vilaine. The Bay of Brest was influenced by marine inputs despite its degree of encloseness. 
Keywords : Bay of Brest ; Bay of Vilaine ; Benthic ; filter-feeders ; stable isotopes ; organic matter

\section{Introduction}

Coastal ecosystems are places of intense biogeochemical activity, where both continental (through freshwater runoff) and oceanic inputs (through upwellings and tidal mixing) contribute to their high biological productivity and their important role in the global cycle of carbon, nitrogen and phosphorus (Gattuso et al., 1998). For instance, Cole et al. (2007) estimated worldwide that over 0.9 Pg C is annually exported by the rivers to the oceans. This carbon can either be buried in coastal sediments, exported to the open ocean, or enter coastal food webs. Studying the fate of terrestrial organic matter in these environments is therefore of considerable importance. In coastal estuarine embayments, the retention of water masses due to coastline topography should result in an increased contribution of continental organic matter to the associated communities, compared to open coastline areas. However, the effect of topography can be counterbalanced in megatidal areas by the process of tidal mixing. The relative importance of these different factors on the fate of terrestrial matter in coastal and neighboring communities is a significant step toward the understanding of the role played by coastal habitats as an interface between continental and marine ecosystems.

The influence of terrestrial organic matter from large rivers (e.g. Rhône river, Danube river) proved to be significant on coastal communities down to deeper waters (to $100 \mathrm{~m}$, Darnaude et al., 2004). However, the few studies investigating the effects of small rivers showed a very limited bathymetric effect on the stable isotope ratios of coastal biota (Connolly et al., 2009). Nevertheless, all these studies agreed in showing that the effects of terrestrial inputs were maximal on deposit feeders, which ingest sedimented particles on the seafloor.

Stable isotope analyses have proven in the past thirty years to be a powerful tool to investigate the assimilation of terrestrial organic matter into coastal food webs. In temperate areas, catchments are generally dominated by $\mathrm{C}_{3}$ plants, that typically display ${ }^{13} \mathrm{C}$ depleted signatures (around $-28 \%$, Peterson and Fry, 1987). Detritus from $\mathrm{C}_{3}$ plants may constitute therefore the largest part of organic matter brought to the coastal environment by estuaries. This organic matter can easily be distinguished from marine primary producers, which display ${ }^{13} \mathrm{C}$ enriched signatures (Peterson and Fry, 1987). In addition, particulate organic matter and 
nutrients brought to the coastal ocean by rivers are generally ${ }^{15} \mathrm{~N}$ enriched, compared to coastal primary producers, due to anthropogenic activities (McClelland et al., 1997; Riera et al., 2000), hence allowing efficient characterization of riverine inputs into coastal food webs. Consequently, the use of stable isotopes is currently the most popular one to address the origin of organic matter in coastal ecosystems (e.g. Darnaude et al., 2004; Banaru et al., 2007; Connolly et al., 2009; Marchais et al., 2013).

Previous studies trying to characterize the assimilation of terrestrial material into coastal food webs in Western Europe using stable isotopes have shown the importance of freshwater discharge for the food web associated to juvenile flatfish in the Bay of Vilaine ( Kostecki et al., 2010; Kopp et al., 2013), as well as marked isotopic gradients reflected in oysters along an estuarine gradient in the Bay of Brest (Marchais et al., 2013). At a larger scale, depth gradients affecting both carbon and nitrogen isotopic ratios suggested that the influence of small rivers might propagate down to the entire continental shelf scale (Nerot et al., 2012). These studies provide consistent evidence that even small rivers can significantly affect their neighboring coastal communities. However, comparison among dissimilar environmental systems would provide additional information on ecological mechanisms affecting the spatial and temporal extent of organic matter exchanges between rivers, estuaries and coastal ecosystems.

Our aim was therefore to assess the fate of terrestrial material on adjacent coastal communities at multi-trophic levels, from primary producers to primary consumers and predators. Two estuarine bays of the French Atlantic coast, differing in their freshwater runoff, tidal amplitude and aperture degree, were compared. Two sampling dates, corresponding to different freshwater runoff conditions, were also compared, and factors affecting the incorporation of terrestrial material into coastal communities were expected to be identified.

\section{Material and methods}

\subsection{Study area}

This study was conducted on the northern coast of the Bay of Biscay, in the Bay of Brest and the Bay of Vilaine (Fig. 1). The Bay of Brest is a semi-enclosed ecosystem of more than $100 \mathrm{~km}^{2}$, connected to the Iroise Sea by a $2 \mathrm{~km}$ wide and $40 \mathrm{~m}$ deep channel. Most of freshwater inputs to the bay originate from the Elorn and the Aulne rivers, which drain a total catchment of $2135 \mathrm{~km}^{2}$. Maximal tidal amplitude reaches $8 \mathrm{~m}$ and the daily water inflow 
from the ocean into the bay $\left(1310^{8} \mathrm{~m}^{3}\right)$ reach the annual freshwater volume discharge by the two rivers $\left(1110^{8} \mathrm{~m}^{3} \cdot \mathrm{yr}^{-1}\right.$, Table 1$)$. Such a water inflow combined with the bay surface, leads to strong tidal currents favoring vertical exchange and estuary/ocean water mixing. The Bay of Vilaine, however, receives large freshwater inputs from the Vilaine River $\left(2910^{8} \mathrm{~m}^{3} \cdot \mathrm{yr}^{-1}\right)$, which drains a $10500 \mathrm{~km}^{2}$ catchment (Table 1). The maximal tidal amplitude reaches $5.5 \mathrm{~m}$ and the oscillating volume $\left(14.510^{8} \mathrm{~m}^{3}\right)$ is similar to that of the Bay of Brest. However, the larger surface of the bay coupled to both lower mean depth and larger aperture degree to the open ocean, lead to low water mixing in the estuary. The low currents recorded $\left(0,5 \mathrm{~m} . \mathrm{s}^{-1}\right.$ maximum) lead to active deposition of fine sediment.

Table 1

Fig. 1

\subsection{Sample collection and preparation}

Sampling was carried out in March and May 2008 for the Bay of Vilaine and the Bay of Brest, respectively, as well as in September 2008 for both sampling areas. A different number of stations were sampled within each bay (16 in the Bay of Brest, 10 in the Bay of Vilaine), at depths ranging from 0 to $35 \mathrm{~m}$. An additional survey was conducted in September 2011 in the Bay of Brest focusing on benthic and demersal fish that were not collected in 2008. March and May sampling took place after the most important rain events of winter, while September sampling corresponded to summer conditions, with no important freshwater inputs that occurred in the preceding three months (Fig. 2).

Fig. 2

Depending on the depth and the substratum, benthic fauna was either sampled using a beam trawl (2.9 m wide and $0.5 \mathrm{~m}$ high opening, mesh $1 \mathrm{~cm}$ ), an otter trawl (average $11 \mathrm{~m}$ wide by $2.5 \mathrm{~m}$ high opening, mesh 6 and $2.4 \mathrm{~cm}$ ) or a scallop dredge $(2 \mathrm{~m}$ wide, mesh $5 \mathrm{~cm})$. Mollusks, including suspension-feeding bivalves and the gastropod Crepidula fornicata, as well as demersal fish specimens, were collected from each station. Whenever possible, Acanthocardia tuberculata, Aequipecten opercularis, Mimachlamys varia and Pecten maximus were also collected at each station (Table 2). Benthic fish collected included the Soleidae Buglossidium luteum, Dicologlossa cuneata, and Solea solea, the Gobiidae Gobius niger and Pomatoschistus minutus, and the Gadiformes Merluccius merluccius and Trisopterus luscus (Table 2). Muscle tissues of mollusks and fish were dissected and stored frozen. Muscle tissues were chosen due to their relatively long metabolic turnover time 
(Lorrain et al., 2002; Paulet et al., 2006; Hill and McQuaid, 2009). Samples were then freeze-dried, ground into powder, and weighed in tin cups for $\delta^{13} \mathrm{C}$ and $\delta^{15} \mathrm{~N}$ isotopic analysis at the Sinlab facility (New Brunswick, Canada) using a Costech 4010 elemental analyzer coupled to either a Finnigan Delta Plus or a Finnigan Delta Plus XP mass spectrometer.

Table 2

Seawater was sampled $1 \mathrm{~m}$ above the substratum using a Niskin bottle, to collect suspended particulate organic matter (SPOM) for determination of $\delta^{13} \mathrm{C}$ and $\delta^{15} \mathrm{~N}$ stable isotopes. Seawater was filtered through pre-combusted $\left(450^{\circ} \mathrm{C}, 12\right.$ hours) glass fiber filters (Whatman GF/F, $47 \mathrm{~mm}$ ) using a vacuum system under low pressure. These filters were subsequently exposed to $\mathrm{HCl}$ vapour for four hours at room temperature in order to remove carbonates and freeze-dried prior to analysis. Samples were then analyzed at the LIENSs laboratory (La Rochelle, France) using a Thermo Scientific Delta V Advantage mass spectrometer and a Thermo Scientific Flash EA1112 elemental analyzer.

The isotopic ratios $\left({ }^{13} \mathrm{C} /{ }^{12} \mathrm{C}\right.$ or $\left.{ }^{15} \mathrm{~N} /{ }^{14} \mathrm{~N}\right)$ were reported in the standard delta notation $\left(\delta^{13} \mathrm{C}\right.$ or $\delta^{15} \mathrm{~N}$, in \%o), calculated in relation to an international standard (Vienna PeeDee Belemnite for $\delta^{13} \mathrm{C}$ and atmospheric $\mathrm{N}_{2}$ for $\delta^{15} \mathrm{~N}$, Peterson and Fry, 1987):

$\delta^{13} C$ or $\delta^{15} N=\left[\left(R_{\text {Sample }} / R_{S \tan \text { dard }}\right)-1\right] \times 10^{3}$

Analytical precision based on repeated analysis of acetanilide (Thermo Scientific) was $<0.15 \%$ for both carbon and nitrogen.

\subsection{Data analysis}

Depth gradients investigated in this study were obtained through depth estimation from GPS coordinates on EMODnet (European Marine Observation and Data Network) gridded bathymetry metadata. These metadata were obtained through single-beam echosounders for the Iroise Sea and the Vilaine Estuary (SHOM, Service Hydrographique et Océanographique de la Marine).

Prior to further analyses, correlations between stables isotopes composition $\left(\delta^{13} \mathrm{C}\right.$ and $\left.\delta^{15} \mathrm{~N}\right)$ and length or weight of mollusks and fish samples were tested to avoid misinterpretation of data, due to the trophic status of the samples analyzed. Indeed, in aquatic ecosystems, larger organisms may have higher trophic level as they can consume larger and potentially enriched prey items (Badalamenti et al., 2002; Nakazawa et al., 2010). Therefore, correlations between these variables were tested using the non-parametric Spearman correlation test as the 
assumption of normality on residuals was not met in most case. Temporal and depth effects on stable isotope ratios of both SPOM and consumers were investigated using covariance analyses (ANCOVAs: Isotopes $\sim$ depth + sampling time). ANCOVA was therefore used to test the main temporal effects of the factors, while controlling for the effects of the covariate (depth). Indeed, ANCOVA is commonly accepted to be robust to non-normality, heteroscedasticity and most failure of assumptions (Olejnik and Algina, 1984; Warton, 2007). All statistical analyses were implemented within the $\mathrm{R}$ programming environment $(\mathrm{R}$ Development Core Team 2010), with the probability $\alpha$ set at 0.05 .

\section{Results}

\subsection{Suspended particulate organic matter}

Opposite trends were found for SPOM along the gradient for $\delta^{15} \mathrm{~N}$ in the two bays. In the Bay of Vilaine, the highest values were found for upstream stations with offshore stations displaying lowest $\delta^{15} \mathrm{~N}$ (Fig. 3a, ANCOVA, $p<0.05$ ) whereas in the Bay of Brest, an increasing pattern was observed along the depth gradient (Fig. 3b, ANCOVA, $p<0.01$ ). Along both depth gradients, similar patterns of ${ }^{13} \mathrm{C}$ enrichment with increasing depth were found (Fig. 3, ANCOVA, $p<0.01$ ). In the Bay of Vilaine, $\delta^{15} \mathrm{~N}$ measured in September 2008 was slightly higher than in March (Fig. 3a, ANCOVA, $p<0.05$ ), while the high inter- and intra-site variability in the Bay of Brest obscured any possible temporal trend. In the Bay of Vilaine, SPOM was slightly ${ }^{13} \mathrm{C}$ enriched in March compared to September (Fig. 3a, ANCOVA, $p<0.05)$.

Fig. 3

\subsection{Suspension-feeders}

Several significant correlations were found between stable isotope ratios of Acanthocardia tuberculata, Aequipecten opercularis, Crepidula fornicata, Mimachlamys varia and Pecten maximus and their length or weight. However, low values of Spearman coefficients suggested that these correlations explained only a minor portion of the total variability (Table 3 ). Correlations of up to $90 \%$ were nevertheless found between $\delta^{15} \mathrm{~N}$ and length for $M$. varia as well as between $\delta^{15} \mathrm{~N}$ and weight for $P$. maximus (Table 3, $p<0.001$ and $p=0.01$, respectively). As most suspension-feeders stable isotope ratios did not differ within each sampling station, the different suspension-feeders species were pooled for the analysis.

Table 3 
An overall pattern of ${ }^{15} \mathrm{~N}$ depletion with increasing depth was found for the 2 bays (Fig. 4 , ANCOVA, $p<0.001)$. This pattern was more obvious in the Bay of Vilaine than in the Bay of Brest. In contrast, although some significant $\delta^{13} \mathrm{C}$ variability occurred along the gradient (Fig. 4, ANCOVA for the Bay of Vilaine, $p<0.001$ ), no clear bathymetric trend could be highlighted. No temporal variability was observed in the $\delta^{15} \mathrm{~N}$ of suspension-feeders in the Bay of Brest (Fig. 4b, ANCOVA, $p>0.05$ ) whereas significant enriched $\delta^{13} \mathrm{C}$ signatures were observed in May in comparison to September (Fig. 4b, ANCOVA, $p<0.001$ ). In the Bay of Vilaine, both $\delta^{13} \mathrm{C}$ and $\delta^{15} \mathrm{~N}$ differed between the two sampling dates (Fig. 4a, ANCOVA, $p>0.05$ ), samples of September being ${ }^{13} \mathrm{C}$ enriched and ${ }^{15} \mathrm{~N}$ depleted compared to samples from May.

Fig. 4

\subsection{Fishes}

Similarly to that observed for the suspension feeders, some correlations were found between the stable isotope ratios of fish and their length and/or weight. These coefficients were however weak and indicated that these correlations only explained a small part of the total variability (Table 4).

Table 4

A similar slope of ${ }^{15} \mathrm{~N}$ depletion with increasing depth observed for mollusks was found for fish in the Bay of Vilaine (Fig. 5a, ANCOVA, $p<0.001$ ). This general trend was also observed in the Bay of Brest for Gobiidae (Fig. 5b), although the $\mathrm{R}^{2}$ value explained only $4 \%$ of the variance. In contrast, $\delta^{13} \mathrm{C}$ did not vary much along the gradient, and despite high variability observed for Gobiidae in the two sampling areas, no general trend could be highlighted. Temporal differences were also recorded for the three fish families in the Bay of Vilaine with ${ }^{15} \mathrm{~N}$ enriched signatures in March compared to September (Fig. 5a, ANCOVA, $p<0.001)$. In contrast, although some significant $\delta^{13} \mathrm{C}$ variability occurred between March and September (Fig. 5a, ANCOVA, $p<0.05$ ), no consistent trend could be highlighted.

Fig. 5

\section{Discussion}

\subsection{Primary producers}

Whatever the site/period sampled, SPOM consistently displayed ${ }^{13} \mathrm{C}$ enrichment patterns along both depth gradients (Fig. 3). Such a result was expected with increasing distance from 
the river as previously described in the Rhone Estuary (Darnaude et al., 2004) in France, the Tagus Estuary (Vinagre et al., 2011) in Portugal and the San Pablo Bay (Fry, 1999) in the US. Low $\delta^{13} \mathrm{C}$ upstream estuaries are usually considered as revealing the contribution of uplandoriginating $\mathrm{C}_{3}$ plants to the pool of SPOM (Riera and Richard, 1997) which seems to be also the case in this study. Our observations appear to contradict those from Marchais et al. (2013), who did not find any clear $\delta^{13} \mathrm{C}$ pattern for SPOM along the estuarine gradient in the Bay of Brest. The aforementioned findings were however obtained from surface water samples, where the influence of freshwater inputs is generally assumed to be higher than above the bottom (Simpson et al., 1990). In addition, samples from Marchais et al. (2013) were collected from the shore, where the influence of local primary production (i.e. macroalgae and benthic microalgae) on the composition of SPOM is likely to affect larger scale isotopic patterns (Takai et al., 2004). Our sampling was carried out in the middle of the Bay, at higher depth, where benthic primary production is reduced by the high turbidity of Western Europe waters. Such contradictions emphasise the variability of local processes occurring on intertidal ecosystems, while subtidal soft-bottom environment are less likely to be affected by small-scale variability, hence reflecting larger scale patterns.

Opposite patterns were found for $\delta^{15} \mathrm{~N}$ along the depth gradient in the two study areas, ${ }^{15} \mathrm{~N}$ enrichment with depth being found in the Bay of Brest, while ${ }^{15} \mathrm{~N}$ depletion was found in the Bay of Vilaine (Fig. 3). The $\delta^{15} \mathrm{~N}$ patterns observed along estuarine gradients are known to be largely related to anthropogenic nitrogen inputs from catchments (Costanzo et al., 2001). The presence of high $\delta^{15} \mathrm{~N}$ for SPOM upstream the Bay of Vilaine (Fig. 3a) confirms this paradigm as previously discussed in the Tagus Estuary (Vinagre et al., 2011) and San Pablo Bay (Fry, 1999). Although the Bay of Brest drains two of the most nitrate-polluted rivers of the French coastline (i.e. Aulne Elorn rivers, CEO-Landerneau et al., 2009), $\delta^{15} \mathrm{~N}$ did not follow that pattern. It is of note that $\delta^{15} \mathrm{~N}$ measured in upstream stations in the Bay of Brest were the most depleted of the entire gradient (Fig. 3b). Since $\delta^{15} \mathrm{~N}$ in primary producers is assumed to be mainly correlated to anthropogenic nitrogen inputs from the rivers (McClelland et al., 1997), the low inflow from the river into the Bay of Brest (Fig. 2, Table 1) may explain such result. Indeed, both samplings in the Bay of Brest were performed during lower flow periods, therefore limiting potentially ${ }^{15} \mathrm{~N}$ enriched inputs. In contrast, the winter sampling (i.e. March) in the Bay of Vilaine has been carried out during a flood event (Fig. 2, appendix 2). Moreover, nitrate estimations (simulated bottom concentrations from ECO-Mars3D model) showed a consistent depletion in the most shallow sites of the Bay of Brest, while the 
entire Bay of Vilaine was characterized by high concentrations over the sampling period (see appendix 1), with an annual flow of nitrogen reaching up to $16000 \mathrm{t}$ (Le Bris and Glemarec, 1995). Despite the enclosed morphology of the Bay of Brest that may induce nutrient accumulation within the Bay, tidal mixing ( $30 \%$ of the bay is renewed at each tidal cycle, Le Pape et al., 1996), phytoplankton consumption of nutrients (see chlorophyll $a$ estimations in appendix 1) and control by benthic suspension-feeder activity (Chauvaud et al., 2000) may together explain low nutrient concentrations, and hence the observed pattern of $\delta^{15} \mathrm{~N}$ in SPOM. During flood periods, nutrient replenishment of the Bay of Brest may be mainly due to oceanic inputs with incoming tide flow (appendix 2), while freshwater inputs represent the main nutrient source of the Bay of Vilaine.

\subsection{Temporal variability}

A notable finding in our study is the lack of temporal variation in the SPOM stable isotope ratios in the Bay of Brest, while temporal variations were observed in the Bay of Vilaine. These results agree with the greater freshwater inflows during the flood (Fig. 2, appendix 2). Such a lack of variation in the Bay of Brest may be related to the control of nutrient and phytoplankton by benthic suspension feeders. This hypothesis can be supported by the capability of the benthic community to filter the water of the bay with a period ( 3 to 5 days) shorter than the hydrodynamic residence time (15 to 30 days), and comparable with the time associated with plankton growth (Hily, 1991). Thus, such control by benthic suspension feeders was also observed by (Chauvaud et al., 2000) who noticed an extensive spreading of the exotic gastropod Crepidula fornicata.

In the Bay of Vilaine, March sampling was carried out during a strong flood event, while September sampling was carried out after the dry summer period (Fig. 2). In this bay, ${ }^{15} \mathrm{~N}$ enriched suspension-feeders and fish in March compared to September suggested higher influence of anthropogenic nitrogen inflow from the river (Figs. 4 and 5). Schlacher et al. (2005) indicated that fish were good bioindicators of nitrogen pollution through anthropogenic waste waters in sub-tropical estuaries of the East Coast Australia. However, these authors did not find any seasonal variation attributed to the slower turnover rate in fish muscle than algae and invertebrates (Hesslein et al., 1993). Our results indicate that demersal fish are not only good spatial bioindicators of anthropogenic nitrogen pollution, but also in some case good temporal tracers.

In accordance with the seasonal contribution of the Vilaine River to the benthic food web of this bay, ${ }^{13} \mathrm{C}$ depleted values were found in suspension-feeders from March (Fig. 4a), related 
to the aforementioned contribution of ${ }^{13} \mathrm{C}$ depleted upland-originating $\mathrm{C}_{3}$ plants (Riera and Richard, 1997). However, no temporal trend in $\delta^{13} \mathrm{C}$ was found in fish (Fig. 5a), which are thus more likely to indicate anthropogenic pollution through nitrogen than carbon stable isotopes as previously suggested by Vizzini and Mazzola (2006).

Freshwater inputs seem therefore to be the main driver of temporal and, to a larger extent, seasonal variability, in the Bay of Vilaine. In contrast, as suggested previously, both sampling carried out in the Bay of Brest correspond to lower freshwater runoff periods, which can explain the lack of temporal variability in both SPOM and $\delta^{15} \mathrm{~N}$ of mollusks (Figs. $3 \mathrm{~b}$ and $4 \mathrm{~b}$ ). Although $\delta^{13} \mathrm{C}$ of mollusks slightly differed between sampling periods in the Bay of Brest (Fig. 4b), the mean difference was lower than 1\%, which is of low biological significance. Overall, the temporal variability of stable isotope ratios in SPOM, mollusks and fish suggest that freshwater inputs play a larger role in the Bay of Vilaine than in the Bay of Brest, in accordance with total freshwater runoff for the two Bays (Fig. 2, Table 2).

\subsection{Depth gradients in consumers}

In contrast to that observed for SPOM (Fig. 3), no $\delta^{13} \mathrm{C}$ pattern was found for suspensionfeeders in the coastal area, neither in the Bay of Brest nor in the Bay of Vilaine (Fig. 4). Since suspension-feeders are usually known to feed within the pool of SPOM (Cloern, 1982; Frechette and Bourget, 1985), the absence of spatial covariation between SPOM and mollusks in the two areas appear somehow surprising. A possible explanation would be a regular selection of a SPOM fraction whose stable isotope ratios is constant along the gradient. Most bivalves have indeed been reported to be able to efficiently select their food source among the composite pool of SPOM, according to size (pre-ingestion selection) or nutritive value of particles (post-ingestion selection) (e.g. Shumway et al., 1985; Lesser et al., 1992; Decottignies et al., 2007). A selection toward phytoplankton, as evidenced by Prins et al. (1996), where stable isotope ratios may not change much along the gradient due to water mixing, and where nutritive value is higher than detrital particles (Langdon and Newell, 1990), would explain the absence of a spatial trend. Another potential explanation lies in the temporal dynamics of SPOM stable isotope ratios. Stable isotopes are temporally integrated markers, and some events that might have affected stable isotope ratios in SPOM weeks or months before sampling, and that are still affecting the signatures in mollusks, cannot be excluded.

The same absence of $\delta^{13} \mathrm{C}$ trend along the gradient was found in fish for the two bays (Fig. 5). Such a result was expected as aside from selectivity and temporal dynamics that may hide 
spatial variability of stable isotope ratios, fish are highly mobile consumers (at least at the bay scale) and have longer tissue renewal time, thus integrating their diet into their tissues for longer periods than bivalves (Hussey et al., 2012). Our observation appears to contradict the findings of Kopp et al. (2013), who found differences in $\delta^{13} \mathrm{C}$ signatures of the common sole between habitats. These differences were associated with ontogenetic changes that fish may undergo during their life cycle, due to habitat changes and prey availability (Werner and Gilliam, 1984). Indeed, lower feeding plasticity of age one group (G1) than young-of-the-year group (G0) was shown for the common sole by Kopp et al. (2013). Although little correlation was recorded between stables isotopes ratios, size and weight for Soleidae (Table 4), the large variability in size of the fish sampled (from 5 to $20 \mathrm{~cm}$ ) over the depth gradient may explain the lack of spatial differences.

Our results on the three trophic levels illustrate the fact that spatial patterns in stable isotope ratios are buffered with increasing level due to different factors (selectivity, temporal dynamics and mobility). Suspension-feeder mollusks consistently displayed a ${ }^{15} \mathrm{~N}$ depletion pattern along the gradient in the two bays (Fig. 4) reflecting the dilution of anthropogenic inputs to the system. Although in the Bay of Vilaine this pattern corresponds to that observed for SPOM, the trends observed for SPOM and mollusks in the Bay of Brest are opposed (Figs. 3 and 4). This again supports the fact that SPOM may not be assimilated by mollusks as a whole, and that some selectivity may occur during ingestion and/or assimilation of particles. In addition, the same pattern in $\delta^{15} \mathrm{~N}$ was found for fish in the Bay of Vilaine (Fig. 5, we could not collect sufficient fish in the Bay of Brest to infer spatially/temporally integrated conclusions), which suggests that the absence of spatial trend in $\delta^{13} \mathrm{C}$ of fish is the result as for mollusks of food selection, higher turnover but also mobility.

\section{Conclusions: ecological functioning of the Bay of Brest and the Bay of Vilaine}

This study indicates the fate of carbon and nitrogen natural stable isotopes in the food web of two contrasting embayments. In the Bay of Vilaine, results obtained for SPOM, mollusks and fish fitted the expected pattern. ${ }^{13} \mathrm{C}$ depleted and ${ }^{15} \mathrm{~N}$ enriched values measured upstream confirmed the role of freshwater and anthropogenic inputs to the Bay. ${ }^{13} \mathrm{C}$ enrichment and ${ }^{15} \mathrm{~N}$ depletion when moving to deeper sites revealed the dilution of these allochtonous inputs. Overall, in this bay, our results highlight the predominant role of freshwater inputs in driving an environmental gradient of relevance for coastal consumer trophic ecology. In contrast, the Bay of Brest appears less impacted by inputs of freshwater. The lack of correspondence between isotopic gradients displayed by SPOM and suspension-feeders suggests that these 
consumers do not assimilate this composite pool as a whole, and that they select a specific fraction whose stable isotope signature is not impacted by inputs of freshwater. However, possible reasons for the apparent lack of freshwater material impact on suspension-feeders in the Bay of Brest include the lack of a flood event during the weeks before sampling, nutrient depletion by phytoplankton production upstream the estuarine bay associated with replenishment from coastal inputs, as well as the efficient selection of highly nutritive phytoplanktonic particles and the integration times of the different trophic levels considered. Overall, despite it being much more enclosed than the Bay of Vilaine, the Bay of Brest appears to be highly influenced by marine inputs.

Stable isotopes in coastal consumers are increasingly used as markers for ecosystem typology (Fertig et al., 2009; Lefebvre et al., 2009; Marchais et al., 2013). In our study, as expected, depth-related isotopic gradients were less marked for primary consumers than for SPOM, and for fish than for primary consumers. This emphasises the need to carefully consider the choice of model organisms for these approaches. Factors such as integration time (i.e. turnover in consumers) and mobility can affect their susceptibility to reflect ecological patterns (such as, in our study, depth and freshwater input gradients) as different spatial scales. Rapidly integrating biota (e.g. SPOM, primary producers or small primary consumers) should be preferred to infer the impact of small scale (spatial and/or temporal) processes, while longer integrating organisms (larger consumers) will be more efficient in revealing larger scale processes.

\section{Acknowledgements}

This research is a contribution to the RETROCAN and MORESCA projects, respectively supported by Ifremer and Insu (EC2CO-PNEC project) and the European University of Brittany (UEB). We thank the crews of the Research Vessels "Albert Lucas" (UBO) and "Gwen Drez" (Ifremer) for sampling facilities and assistance during the work at sea.

\section{References}

Badalamenti, F., D'Anna, G., Pinnegar, J.K., Polunin, N.V.C., 2002. Size-related trophodynamic changes in three target fish species recovering from intensive trawling. Marine Biology 141, 561-570.

Banaru, D., Harmelin-Vivien, M., Gomoiu, M.T., Onciu, T.M., 2007. Influence of the Danube River inputs on $\mathrm{C}$ and $\mathrm{N}$ stable isotope ratios of the Romanian coastal waters and sediment (Black Sea). Marine Pollution Bulletin 54, 1385-1394. 
CEO-Landerneau, AG-LB, DIREN-Bretagne, 2009. Fiche de synthèse - Concentrations en nitrates. Bretagne-environnement.

Chauvaud, L., Jean, F., Ragueneau, O., Thouzeau, G., 2000. Long-term variation of the Bay of Brest ecosystem: benthic-pelagic coupling revisited Marine Ecology Progress Series 200, 35-48.

Cloern, J.E., 1982. Does the benthos control phytoplankton biomass in south San Francisco Bay? Marine Ecology Progress Series 9, 191-202.

Cole, J.J., Prairie, Y.T., Caraco, N.F., McDowell, W.H., Tranvik, L.J., Striegl, R.G., Duarte, C.M., Kortelainen, P., Downing, J.A., Middelburg, J.J., Melack, J., 2007. Plumbing the global carbon cycle: Integrating inland waters into the terrestrial carbon budget. Ecosystems 10, 171-184.

Connolly, R.M., Schlacher, T.A., Gaston, T.F., 2009. Stable isotope evidence for trophic subsidy of coastal benthic fisheries by river discharge plumes off small estuaries. Marine Biology Research 5, 164-171.

Costanzo, S.D., O'Donohue, M.J., Dennison, W.C., Loneragan, N.R., Thomas, M., 2001. A new approach for detecting and mapping sewage impacts. Marine Pollution Bulletin 42, 149-156.

Darnaude, A.M., Salen-Picard, C., Harmelin-Vivien, M.L., 2004. Depth variation in terrestrial particulate organic matter exploitation by marine coastal benthic communities off the Rhone River delta (NW Mediterranean). Marine Ecology-Progress Series 275, 47-57.

Decottignies, P., Beninger, P.G., Rince, Y., Robins, R.J., Riera, P., 2007. Exploitation of natural food sources by two sympatric, invasive suspension-feeders: Crassostrea gigas and Crepidula fornicata. Marine Ecology Progress Series 334, 179-192.

De Nadaillac, G., Breton, M., 1986. Les courants an baie de Vilaine - Synthèse des Résultats IFREMER, BREST, p. 34.

Fertig, B., Carruthers, T.J.B., Dennison, W.C., Jones, A.B., Pantus, F., Longstaff, B., 2009. Oyster and macroalgae bioindicators detect elevated $\delta^{15} \mathrm{~N}$ in Maryland's Coastal Bays.

Estuaries and Coasts 32, 773-786.

Frechette, M., Bourget, E., 1985. Energy flow between the pelagic and benthic zones: Factors controlling particulate organic matter available to an intertidal mussel bed. Canadian Journal of Fisheries and Aquatic Sciences 42, 1158-1165.

Fry, B., 1999. Using stable isotopes to monitor watershed influences on aquatic trophodynamics. Canadian Journal of Fisheries and Aquatic Sciences 56, 2167-2171. 
Gattuso, J.P., Frankignoulle, M., Wollast, R., 1998. Carbon and carbonate metabolism in coastal aquatic ecosystems. Annual Review of Ecology and Systematics 29, 405-434.

Hesslein, R.H., Hallard, K.A., Ramlal, P., 1993. Replacement of sulfur, carbon, and nitrogen in tissue of growing broad whitefish (Coregonus nasus) in response to change in diet traced by $\delta^{34} \mathrm{~S}, \delta^{13} \mathrm{C}$ and $\delta^{15} \mathrm{~N}$. Canadian Journal of Fisheries and Aquatic Sciences 50, 2071-2076. Hill, J.M., McQuaid, C.D., 2009. Effects of food quality on tissue-specific isotope ratios in the mussel Perna perna. Hydrobiologia 635, 81-94.

Hily, C., 1991. Is the activity of benthic suspension feeders a factor controlling water quality in the Bay of Brest. Marine Ecology Progress Series 69, 179-188.

Hussey, N.E., MacNeil, M.A., Olin, J.A., McMeans, B.C., Kinney, M.J., Chapman, D.D., Fisk, A.T., 2012. Stable isotopes and elasmobranchs: tissue types, methods, applications and assumptions. Journal of Fish Biology 80, 1449-1484.

Kopp, D., Le Bris, H., Grimaud, L., Nerot, C., Brind'Amour, A., 2013. Spatial analysis of the trophic interactions between two juvenile fish species and their preys along a coastal-estuarine gradient. Journal of Sea Research 81, 40-48.

Kostecki, C., Le Loc'h, F., Roussel, J.M., Desroy, N., Huteau, D., Riera, P., Le Bris, H., Le Pape, O., 2010. Dynamics of an estuarine nursery ground: the spatio-temporal relationship between the river flow and the food web of the juvenile common sole (Solea solea, L.) as revealed by stable isotopes analysis. Journal of Sea Research 64, 54-60.

Langdon, C.J., Newell, R.I.E., 1990. Utilization of detritus and bacteria as food source by two bivalve suspension-feeders, the oyster Crassostrea virginica and the mussel Geukensia demissa. Marine Ecology Progress Series 58, 299-310.

Le Bris, H., Glemarec, M., 1995. Macrozoobenthic communities of an oxygen under-saturated coastal ecosystem: The Bay of Vilaine (Southern Brittany). Oceanologica Acta 18, 573-581.

Le Pape, O., Del Amo, Y., Menesguen, A., Aminot, A., Quequiner, B., Treguer, P., 1996. Resistance of a coastal ecosystem to increasing eutrophic conditions: The Bay of Brest (France), a semi-enclosed zone of Western Europe. Continental Shelf Research 16, 1885-1907.

Lefebvre, S., Harma, C., Blin, J.L., 2009. Trophic typology of coastal ecosystems based on $\delta^{13} \mathrm{C}$ and $\delta^{15} \mathrm{~N}$ ratios in an opportunistic suspension feeder. Marine Ecology Progress Series $390,27-37$. 
Lesser, M.P., Shumway, S.E., Cucci, T., Smith, J., 1992. Impact of fouling organisms on mussel rope culture: Interspecific competition for food among suspension-feeding invertebrates. Journal of Experimental Marine Biology and Ecology 165, 91-102. Lorrain, A., Paulet, Y.M., Chauvaud, L., Savoye, N., Donval, A., Saout, C., 2002. Differential $\delta^{13} \mathrm{C}$ and $\delta^{15} \mathrm{~N}$ signatures among scallop tissues: implications for ecology and physiology. Journal of Experimental Marine Biology and Ecology 275, 47-61.

Marchais, V., Schaal, G., Grall, J., Lorrain, A., Nerot, C., Richard, P., Chauvaud, L., 2013. Spatial variability of stable isotope ratios in oysters (Crassostrea gigas) and primary producers along an estuarine gradient (Bay of Brest, France). Estuaries and Coasts 36, 808-819.

McClelland, J.W., Valiela, I., Michener, R.H., 1997. Nitrogen-stable isotope signatures in estuarine food webs: A record of increasing urbanization in coastal watersheds. Limnology and Oceanography 42, 930-937.

Nakazawa, T., Sakai, Y., Hsieh, C.H., Koitabashi, T., Tayasu, I., Yamamura, N., Okuda, N., 2010. Is the relationship between body size and trophic niche position time-invariant in a predatory fish? First stable isotope evidence. Plos One 5, e9120. Nerot, C., Lorrain, A., Grall, J., Gillikin, D.P., Munaron, J.-M., Le Bris, H., Paulet, Y.-M., 2012. Stable isotope variations in benthic filter feeders across a large depth gradient on the continental shelf. Estuarine Coastal and Shelf Science 96, 228-235.

Olejnik, S.F., Algina, J., 1984. Parametric ANCOVA and the rank transform ANCOVA when the data are conditionally non-normal and heteroscedastic. Journal of Educational and Behavioral Statistics 9, 129-149.

Paulet, Y.-M., Lorrain, A., Richard, J., Pouvreau, S., 2006. Experimental shift in $\operatorname{diet} \delta^{13}$ C: A potential tool for ecophysiological studies in marine bivalves. Organic Geochemistry 37 , 1359-1370.

Peterson, B.J., Fry, B., 1987. Stable isotopes in ecosystem studies. Annual Review of Ecology and Systematics 18, 293-320.

Prins, T.C., Smaal, A.C., Pouwer, A.J., Dankers, N., 1996. Filtration and resuspension of particulate matter and phytoplankton on an intertidal mussel bed in the Oosterschelde estuary (SW Netherlands). Marine Ecology Progress Series 142, 121-134.

Riera, P., Richard, P., 1997. Temporal variation of $\delta^{13} \mathrm{C}$ in particulate organic matter and oyster Crassostrea gigas in Marennes-Oleron Bay (France): Effect of freshwater inflow. Marine Ecology-Progress Series 147, 105-115. 
Riera, P., Stal, L.J., Nieuwenhuize, J., 2000. Heavy $\delta^{15} \mathrm{~N}$ in intertidal benthic algae and invertebrates in the Scheldt Estuary (The Netherlands): Effect of river nitrogen inputs. Estuarine Coastal and Shelf Science 51, 365-372.

Schlacher, T.A., Liddell, B., Gaston, T.F., Schlacher-Hoenlinger, M., 2005. Fish track wastewater pollution to estuaries. Oecologia 144, 570-584.

Shumway, S.E., Cucci, T.L., Newell, R.C., Yentsch, C.M., 1985. Particle selection, ingestion, and absorption in filter-feeding bivalves. Journal of Experimental Marine Biology and Ecology 91, 77-92.

Simpson, J.H., Brown, J., Matthews, J., Allen, G., 1990. Tidal straining, density currents, and stirring in the control of estuarine stratification. Estuaries 13, 125-132.

Takai, N., Yorozu, A., Tanimoto, T., Hoshika, A., Yoshihara, K., 2004. Transport pathways of microphytobenthos-originating organic carbon in the food web of an exposed hard bottom shore in the Seto Inland Sea, Japan. Marine Ecology Progress Series 284, 97-108.

Vinagre, C., Maguas, C., Cabral, H.N., Costa, M.J., 2011. Spatial variation in river runoff into a coastal area - An ecological approach. Journal of Sea Research 65, 362-367.

Vizzini, S., Mazzola, A., 2006. The effects of anthropogenic organic matter inputs on stable carbon and nitrogen isotopes in organisms from different trophic levels in a southern Mediterranean coastal area. Science of the Total Environment 368, 723-731.

Warton, D.I., 2007. Robustness to failure of assumptions of tests for a common slope amongst several allometric lines a simulation study. Biometrical Journal 49, 286-299.

Werner, E.E., Gilliam, J.F., 1984. The ontogenetic niche and species interactions in size structured populations. Annual Review of Ecology and Systematics 15, 393-425. 
$4.7^{\circ} \mathrm{W} \quad 4.6^{\circ} \mathrm{W} \quad 4.5^{\circ} \mathrm{W} \quad 4.4^{\circ} \mathrm{W} \quad 4.3^{\circ} \mathrm{W} \quad 4.2^{\circ} \mathrm{W}$

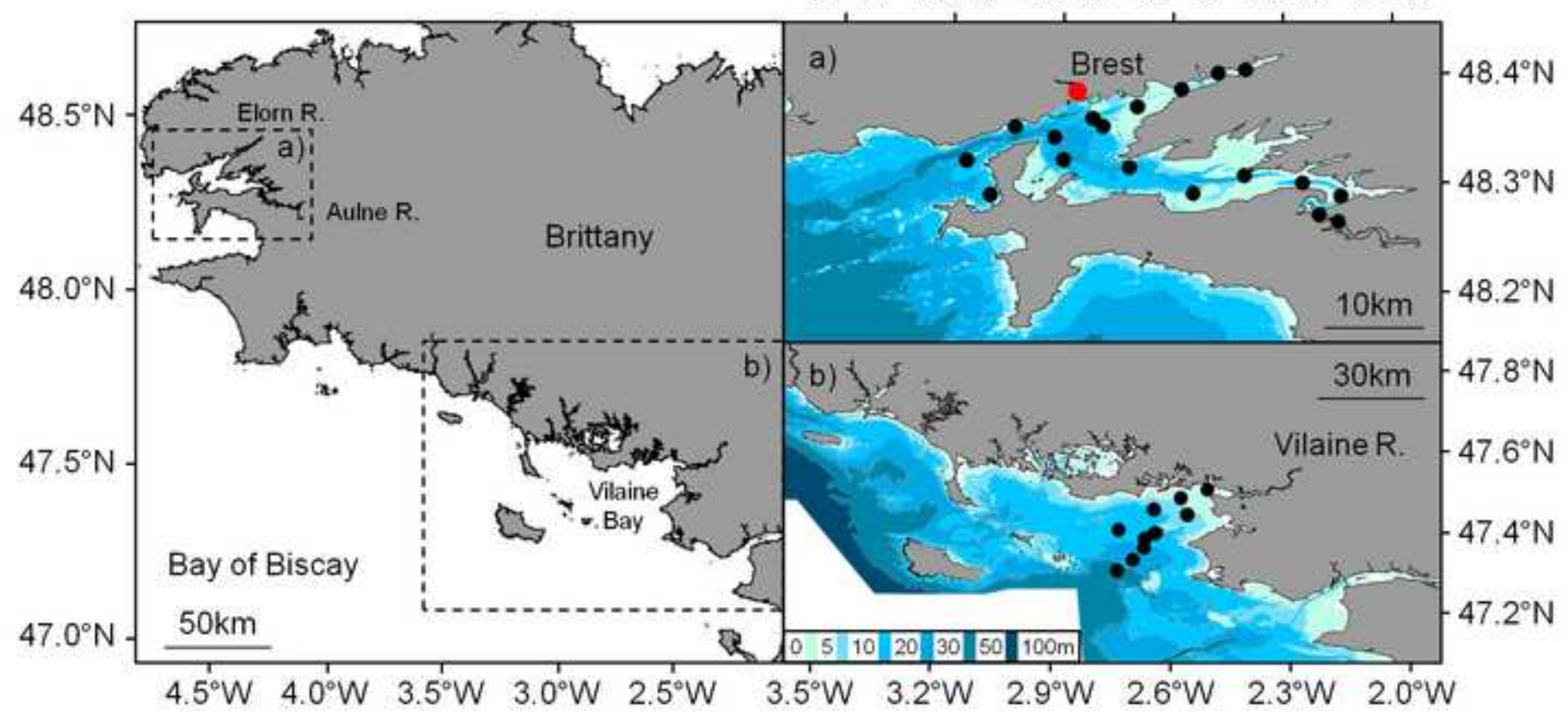


Click here to download high resolution image

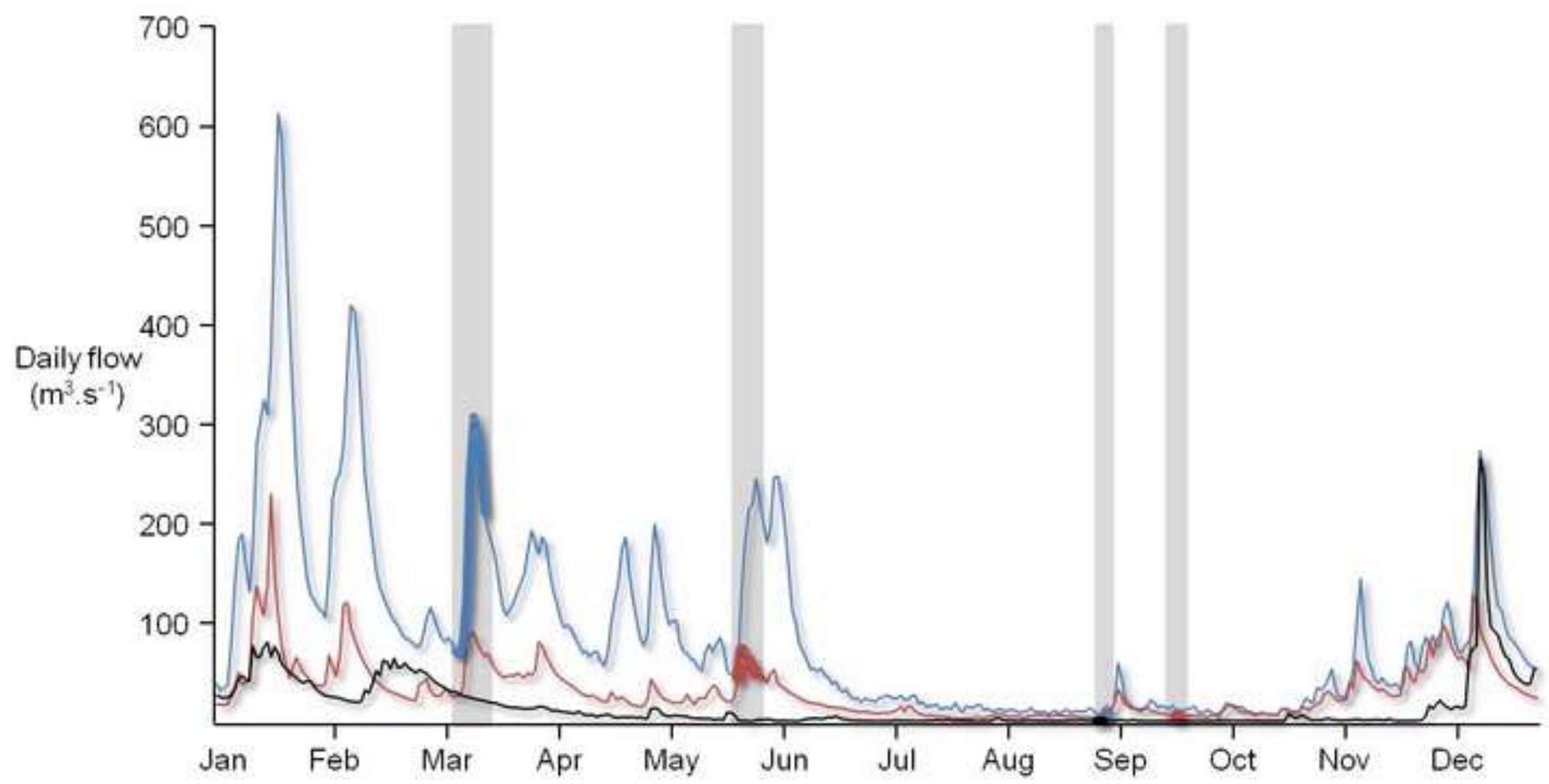




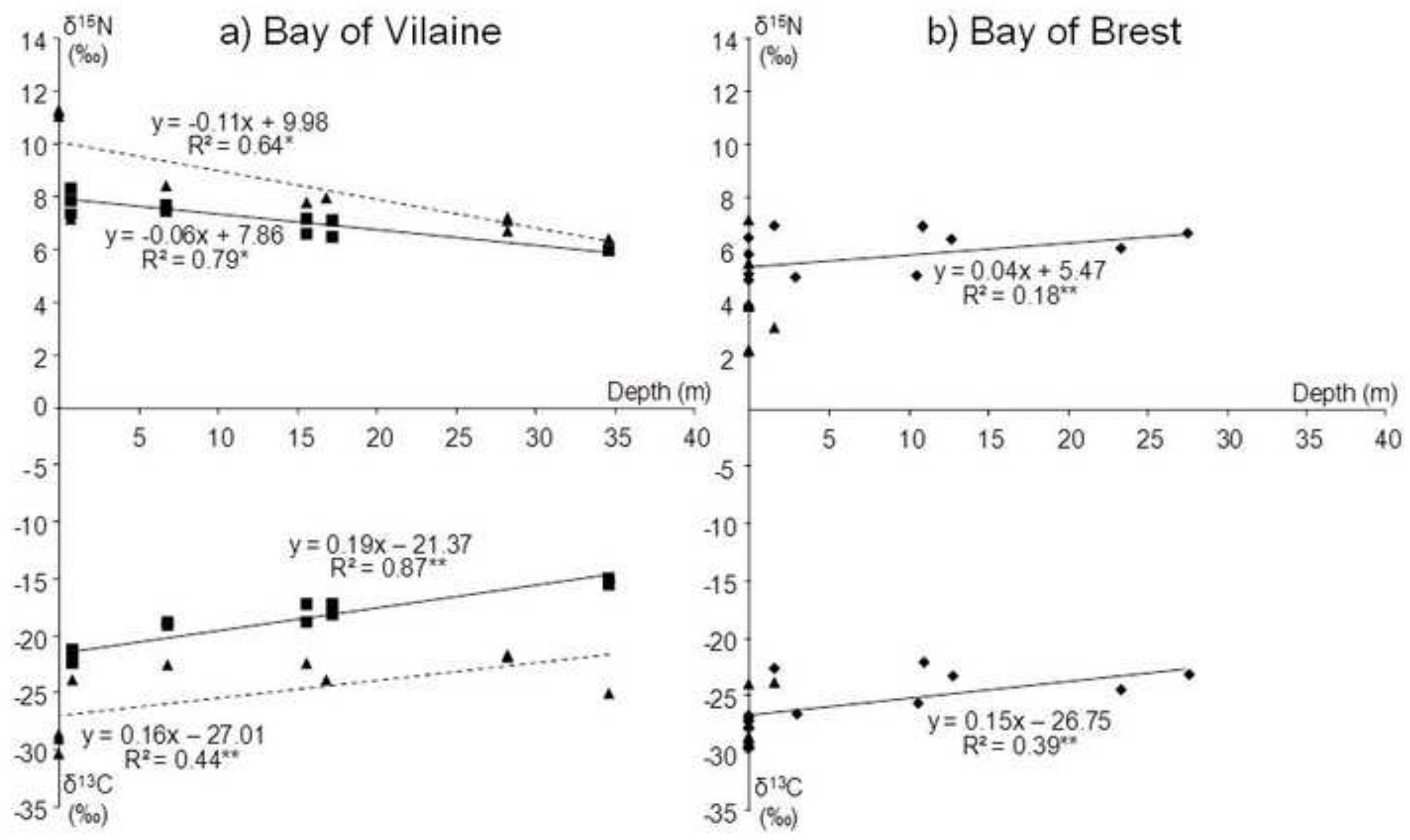




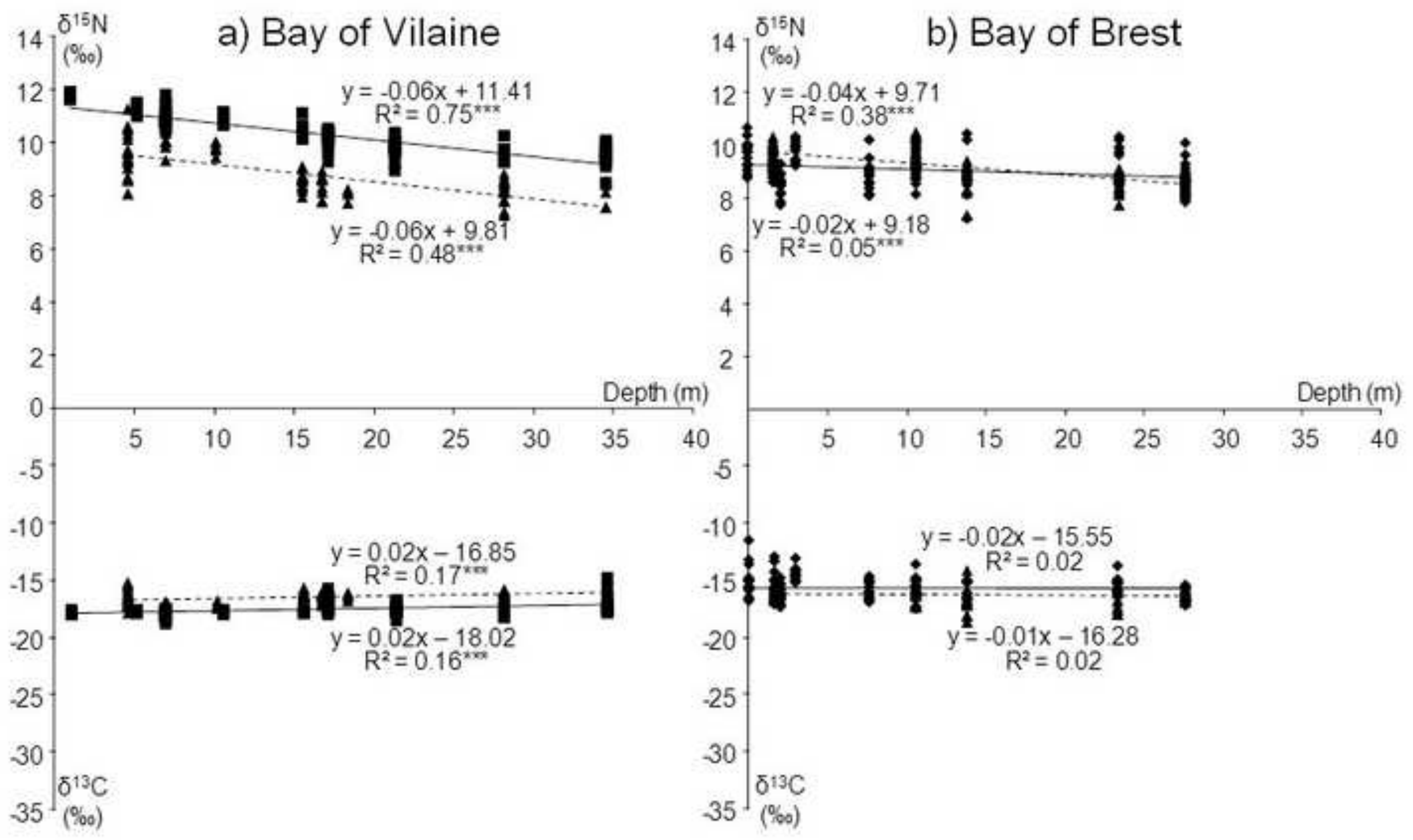




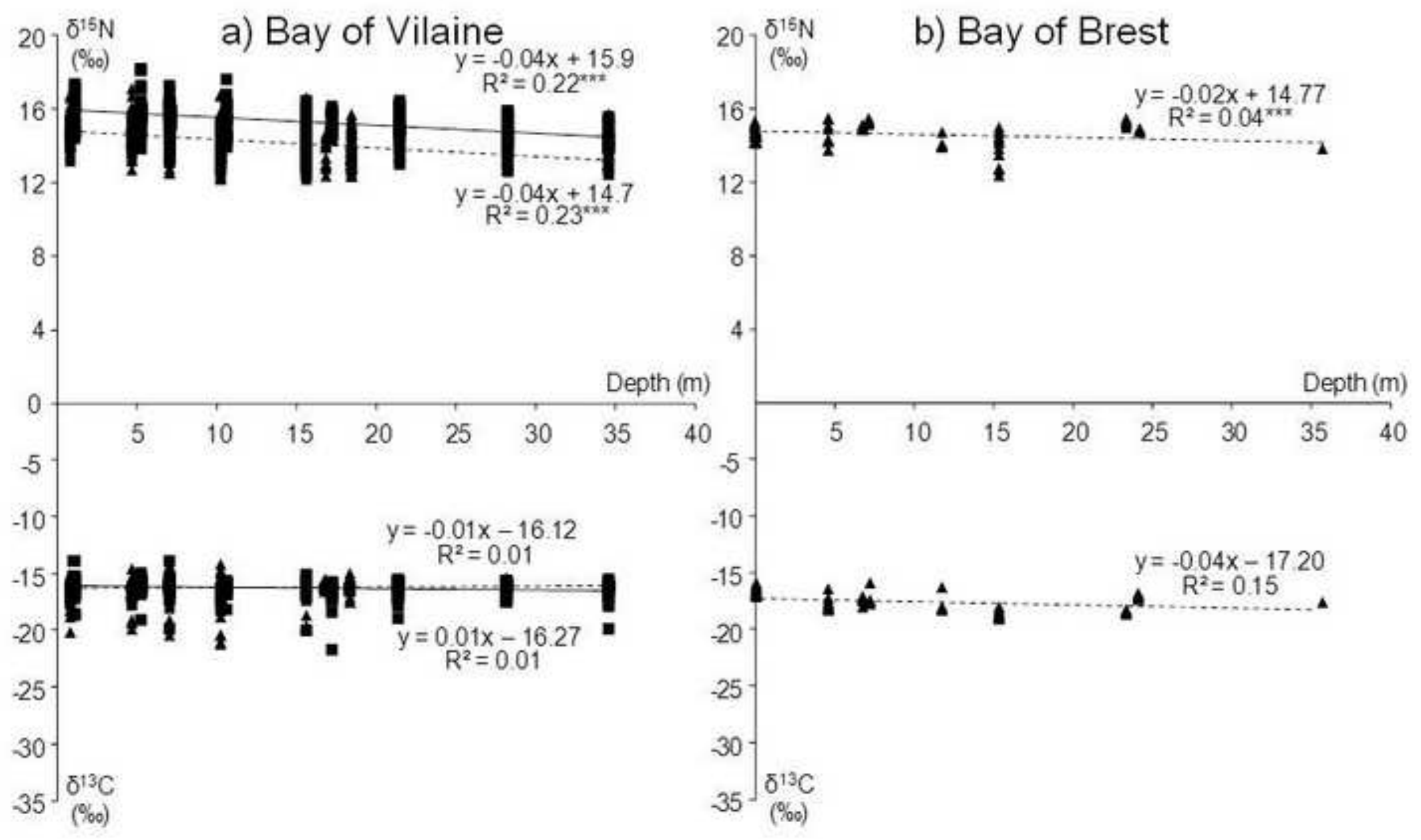




\section{Figures}

Fig. 1. Study area on the northern Bay of Biscay (France). Framed areas highlight the different sampling sites located on (a) the Bay of Brest and (b) the Bay of Vilaine. The blue shades indicate the average depth from 0 to $100 \mathrm{~m}$.

Fig. 2. Daily flows of sampled rivers. Bolds bars indicate sampling periods. Blue line is for the Vilaine River in 2008, red line for the sum of Aulne and Elorn rivers in 2008 and black line for 2011. Source: DREAL Bretagne/HYDRO - MEDD/DE

Fig. 3. Suspended particulate organic matter (SPOM) $\delta^{15} \mathrm{~N}$ and $\delta^{13} \mathrm{C}$ values along the depth gradient for both Vilaine (a) and Brest (b) bays. Squares ( $\mathbf{a}$ ) are for samples of March 2008 in the Bay of Vilaine, diamonds ( $\bullet$ for samples of May 2008 in the Bay of Brest, and triangles (ム) for samples of September 2008 in both study areas. Note that for September 2008 in the Bay of Brest, SPOM data were only available at shallowest depth. Dashed and solid lines represent the trend and its associated equation. $* p<0.05 ; * * p<0.01$

Fig. 4. Suspension-feeders $\delta^{15} \mathrm{~N}$ and $\delta^{13} \mathrm{C}$ values along the depth gradient for both Vilaine (a) and Brest (b) bays. Squares ( $\mathbf{a}$ ) are for samples of March 2008 in the Bay of Vilaine, diamonds ( $\bullet$ ) for samples of May 2008 in the Bay of Brest, and triangles ( $\boldsymbol{\Delta}$ ) for samples of September 2008 in both study areas. Dashed and solid lines represent the trend and its associated equation. $* * * p<0.001$

Fig. 5. Fish $\delta^{15} \mathrm{~N}$ and $\delta^{13} \mathrm{C}$ values along the depth gradient for both Vilaine (a) and Brest (b) bays. Squares ( $\boldsymbol{\square})$ are for samples of March 2008 in the Bay of Vilaine and triangles ( $\Delta$ ) are for samples of September 2008 and 2011 in the bays of Vilaine and Brest, respectively. Note that for the Bay of Brest, only Gobiidae collected in September 2011 are presented. Dashed and solid lines represent the trend and its associated equation. $* * * p<0.001$ 
Table 1. Bays and upland basins characteristics from Aulne, Elorn and Vilaine rivers

\begin{tabular}{|c|c|c|}
\hline & Iroise Front & Vilaine Estuary \\
\hline Surface $\left(\mathbf{k m}^{2}\right)$ & 102.8 & 227.5 \\
\hline Mean depth (m) & 16 & 7 \\
\hline Volume (low tide - m³) & $16.510^{8}$ & $16.110^{8}$ \\
\hline Volume (high tide $-\mathbf{m}^{3}$ ) & $29.410^{8}$ & $30.610^{8}$ \\
\hline River & Aulne Elorn & Vilaine \\
\hline Catchment area $\left(\mathrm{km}^{2}\right)$ & 1875 & 10500 \\
\hline Length (km) & 140 & 218 \\
\hline \multicolumn{3}{|l|}{ Mean flow $\left(m^{3} s^{-1}\right)$} \\
\hline 2008 & 28 & 92 \\
\hline Max. & 12 & 230 \\
\hline Min. & 2 & 13 \\
\hline Population & $70000 \quad 285000$ & $10^{6}$ \\
\hline Density $\left(\mathrm{km}^{-2}\right)$ & 1100 & 100 \\
\hline
\end{tabular}

Sources: DREAL Bretagne/HYDRO - MEDD/DE - (De Nadaillac \& Breton 1986;

Hily 1991)

Table 2. Number of samples collected for each species in the Bay of Brest and Bay of Vilaine

\begin{tabular}{lllcccc} 
& & \multicolumn{3}{c}{ Iroise Front } & \multicolumn{2}{c}{ Vilaine Estuary } \\
& & May-08 & Sep-08 & Sep-11 & Mar-08 & Sep-08 \\
\cline { 3 - 7 } Bivalves & A. tuberculata & - & - & - & 37 & 28 \\
& A. opercularis & 22 & 19 & 17 & 26 & 26 \\
& M. varia & 14 & 13 & 30 & - & - \\
& P. maximus & 33 & 30 & 3 & - & - \\
\hline Gastropod & C. fornicata & 47 & 17 & - & 19 & 21 \\
\hline \multirow{6}{*}{ Gadiformes } & M. merluccius & - & - & - & 7 & - \\
\multirow{5}{*}{ Gobiidae } & T. luscus & - & - & - & 44 & 360 \\
& G. niger & - & - & 40 & 9 & - \\
\multirow{5}{*}{ Soleidae } & P. minutus & - & - & 11 & 22 & 160 \\
& B. luteum & - & - & 6 & 41 & 204 \\
& D. cuneata & - & - & - & 22 & 105 \\
& S. solea & - & - & - & 58 & 208
\end{tabular}


Table 3. Spearman correlation tests between $\delta^{13} \mathrm{C}$ or $\delta^{15} \mathrm{~N}$ stable isotopes and length $(\mathrm{mm})$ or weight $(\mathrm{g})$ of each filter feeder species. Values in italic $r>0.3$ or $r<-0.3$ (modest correlation) and in bold $\mathbf{r}>\mathbf{0 . 7}$ or $\mathbf{r}<\mathbf{- 0 . 7}$ (strong correlation).

\section{Length (mm) Weight (g)}

\begin{tabular}{lccccc} 
& & $r$ & $p$ & $r$ & $p$ \\
\cline { 2 - 6 } A. tuberculata & $\boldsymbol{\delta}^{\mathbf{1 5}} \mathbf{N}$ & 0.01 & $0.94^{\mathrm{NS}}$ & 0.10 & $0.44^{\mathrm{NS}}$ \\
& $\boldsymbol{\delta}^{\mathbf{1 3}} \mathbf{C}$ & 0.39 & 0.001 & 0.36 & 0.004 \\
\hline \multirow{2}{*}{ A. opercularis } & $\boldsymbol{\delta}^{\mathbf{1 5}} \mathbf{N}$ & -0.05 & $0.66^{\mathrm{NS}}$ & -0.10 & $0.37^{\mathrm{NS}}$ \\
& $\boldsymbol{\delta}^{\mathbf{1 3}} \mathbf{C}$ & 0.37 & 0.001 & 0.38 & 0.0002 \\
\hline \multirow{2}{*}{ C. fornicata } & $\boldsymbol{\delta}^{\mathbf{1 5}} \mathbf{N}$ & 0.02 & $0.85^{\mathrm{NS}}$ & 0.008 & $0.94^{\mathrm{NS}}$ \\
& $\boldsymbol{\delta}^{\mathbf{1 3}} \mathbf{C}$ & 0.40 & $210^{-5}$ & 0.50 & $810^{-7}$ \\
\hline \multirow{2}{*}{ M. varia } & $\boldsymbol{\delta}^{\mathbf{1 5}} \mathbf{N}$ & $\mathbf{0 . 8 9}$ & $\mathbf{2 1 0}^{-\mathbf{6}}$ & 0.37 & 0.04 \\
& $\boldsymbol{\delta}^{\mathbf{1 3}} \mathbf{C}$ & 0.46 & $0.06^{\mathrm{NS}}$ & 0.24 & $0.21^{\mathrm{NS}}$ \\
\hline \multirow{2}{*}{ P. maximus } & $\boldsymbol{\delta}^{\mathbf{1 5}} \mathbf{N}$ & 0.38 & 0.002 & $\mathbf{0 . 9 0}$ & $\mathbf{0 . 0 1}$ \\
& $\boldsymbol{\delta}^{\mathbf{1 3}} \mathbf{C}$ & 0.07 & $0.56^{\mathrm{NS}}$ & 0.54 & $0.30^{\mathrm{NS}}$
\end{tabular}

Table 4. Summary of Spearman correlation tests between $\delta^{13} \mathrm{C}$ or $\delta^{15} \mathrm{~N}$ stables isotopes and length $(\mathrm{cm})$ or weight $(\mathrm{g})$ of each fish family. Values in italic $r>0.3$ or $r<-0.3$ (modest correlation).

\section{Length (cm) Weight (g)}

\begin{tabular}{cccccc} 
& & $r$ & $p$ & $r$ & $p$ \\
\cline { 2 - 6 } Gadidae & $\boldsymbol{\delta}^{\mathbf{1 5}} \mathbf{N}$ & 0.29 & $310^{-9}$ & 0.33 & $110^{-11}$ \\
& $\boldsymbol{\delta}^{\mathbf{1 3}} \mathbf{C}$ & 0.39 & $510^{-16}$ & 0.41 & $210^{-16}$ \\
\hline \multirow{2}{*}{ Gobiidae } & $\boldsymbol{\delta}^{\mathbf{1 5}} \mathbf{N}$ & 0.35 & $110^{-8}$ & 0.40 & $810^{-11}$ \\
& $\boldsymbol{\delta}^{\mathbf{1 3}} \mathbf{C}$ & 0.18 & 0.004 & 0.08 & $0.22^{\mathrm{NS}}$ \\
\hline \multirow{2}{*}{ Soleidae } & $\boldsymbol{\delta}^{\mathbf{1 5}} \mathbf{N}$ & -0.03 & $0.43^{\mathrm{NS}}$ & -0.10 & 0.01 \\
& $\boldsymbol{\delta}^{\mathbf{1 3}} \mathbf{C}$ & 0.19 & $110^{-6}$ & 0.21 & $610^{-8}$
\end{tabular}



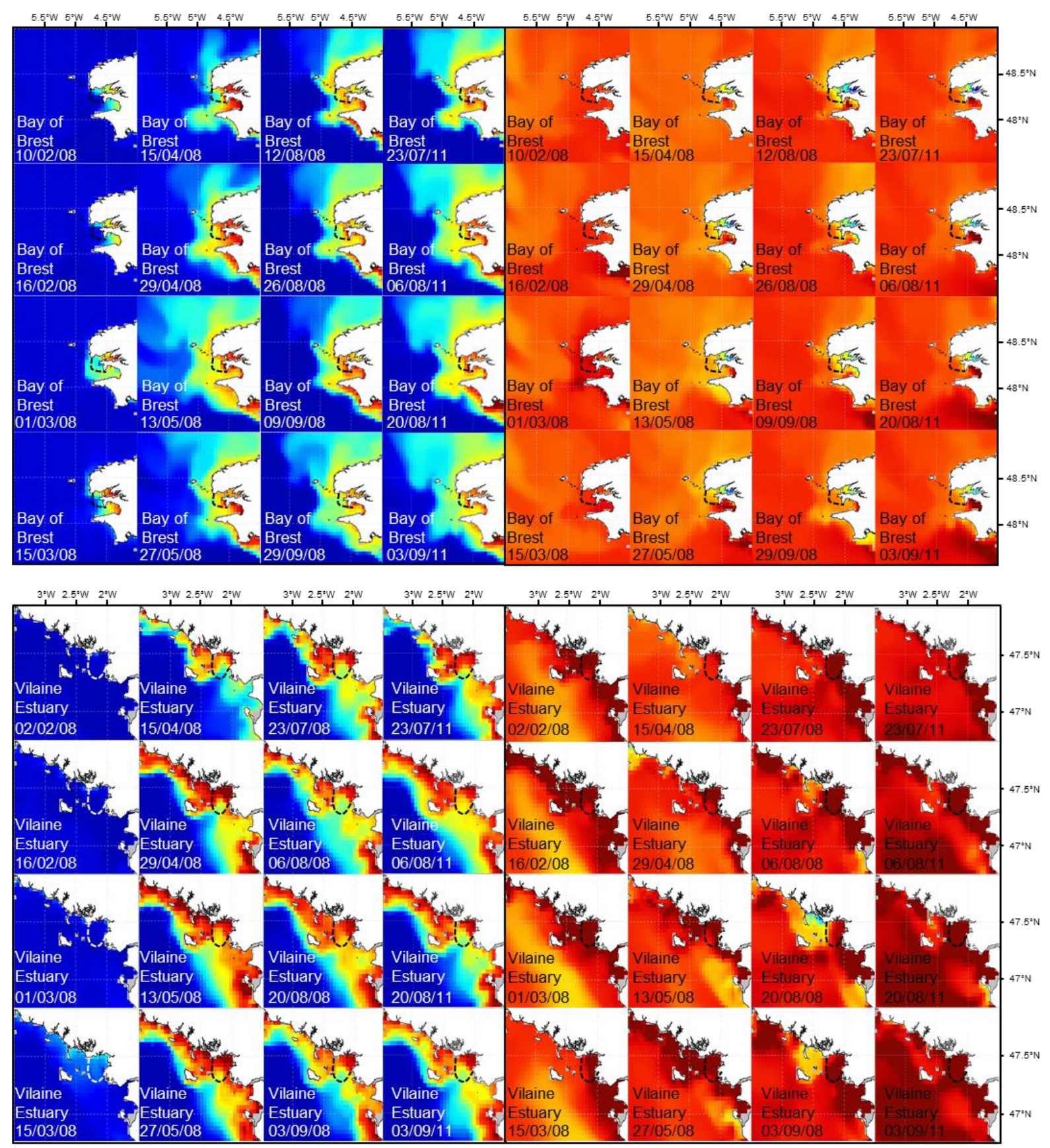

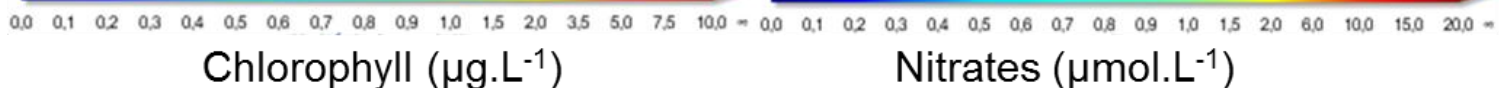

Appendix 1. Diagram showing the chlorophyll and nitrates simulated bottom concentrations from ECO-Mars3D model in the Bay of Brest (top) and the Bay of Vilaine (bottom). 

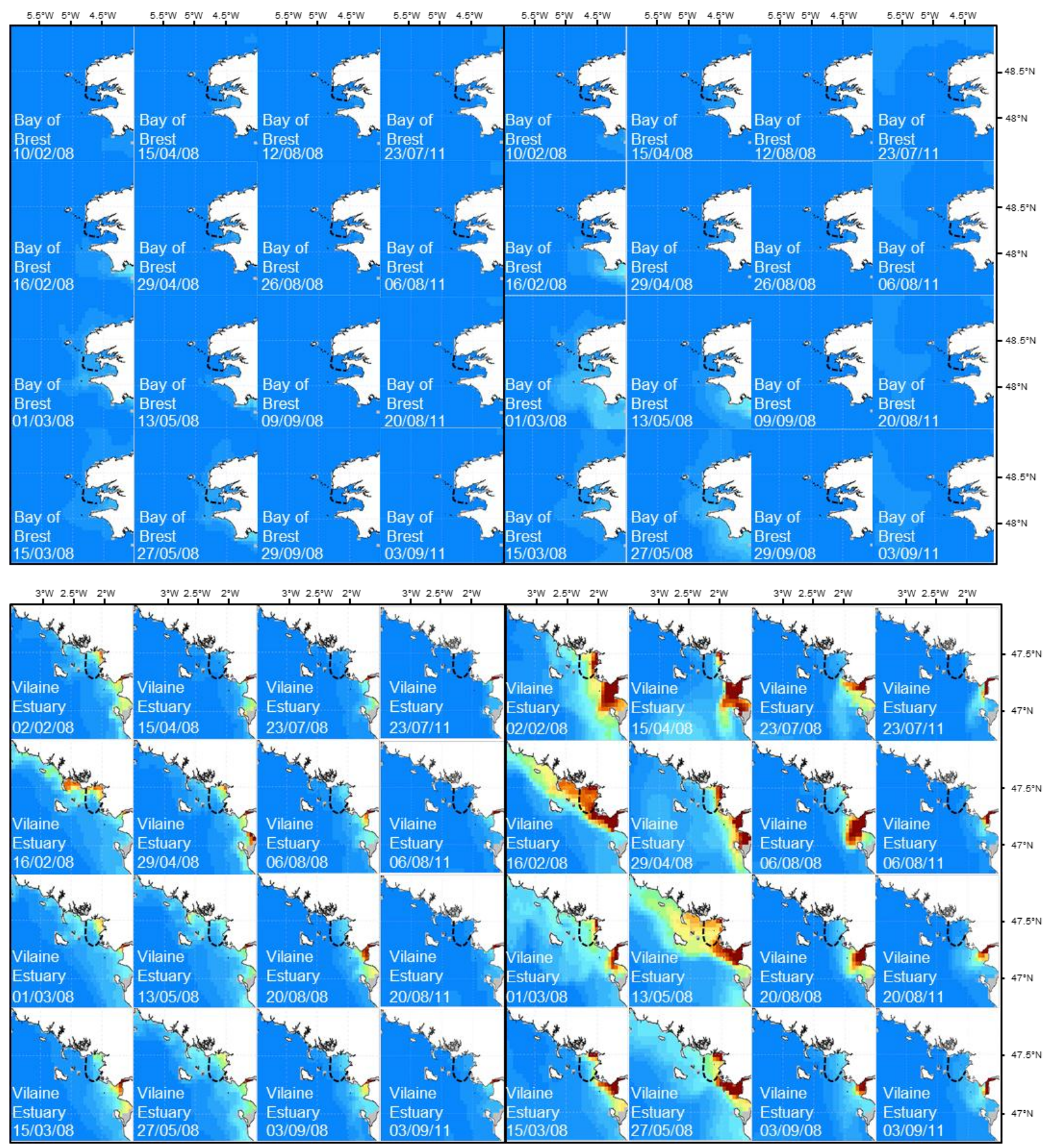

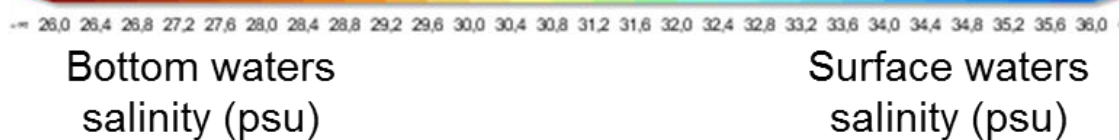

Appendix 2. Diagram showing the simulated bottom (left) and surface (right) waters salinity from ECO-Mars3D model in the Bay of Brest (top) and the Bay of Vilaine (bottom). 